\title{
Consumer Protection: An Analysis for Albania's Positive Steps Towards Greater Protection
}

\author{
MSc. Belinda Halilaj \\ “Ismail Qemali”University, Vlora, Albania; Email: belinda2012halilaj@gmail.com
}

Doi:10.5901/mjss.2016.v7n6p73

\begin{abstract}
It is evident that Albania is taking positive steps towards the highest level of consumer protection. Consumer rights protection was a concept that was initially articulated after the ' 90 s, considering that in the previous communist regime we only had the interaction between the seller and the buyer, as everything was controlled by the state. It was impossible to claim legal consumer protection at the time, the way we do now. Nowadays we convincingly assert that the Albanian consumer fully enjoys its rights and fulfils all the obligations set forward by the law. Buying expensively in the market does not mean that you are buying safe. Knowing what and where you are buying means protecting your health and that of the other persons around you. The measures undertaken by the Albanian government to protect the consumers have proved to be positive and have impacted the increase of quality and the achievement of safety on what the Albanian consumer has access to in the market. This paper indicates the measures undertaken by our country for the protection of consumers.
\end{abstract}

Keywords: consumer protection, health safety, labelling, National Food Authority, safety.

\section{Introduction}

During the communist regime, everything was controlled by the state in Albania and we cannot refer to consumer rights protection. This area of "the right" gained terrain (Malltezi, 2001) during the period of democracy (Omari, 2004). In the last couple of years, our country has approved laws for the consumer as well as implemented several policies that protect the consumer. The approval of the consumer protection law was Albania's first momentum, representing a very important step forward ${ }^{1}$. Considering that until the overthrow of the communist regime the term consumer was not recognized, the approval of such law was a challenge for the society, therefore this law constituted a general arrangement for the consumer's right (Teliti, 2013). Following the changing of economical and social conditions, this law was abrogated, leading to the approval of the law of 2003, which offered greater protection for the consumer as compared to the previous law (Law no. 9135,"For the protection of the consumer", 2003). Consumers enjoy equal protection before the law (Anastasi, Bozo, Mandro, Shkurti, 2014). Based on the constitutional principles, they are all equal before the law (Constitution of the Republic of Albania, Article 18 ).

The necessity of protecting consumer's rights has been growing. The law of 2008 would mark a key momentum and would offer the adequate protection to the consumer (Law no. 9902, "For the protection of the consumer", 2008). By signing the SAA, the parties committed to fully align the Albanian legislation in the area of consumer protection with the acquis communautaire.In the agreement, the parties commit to achieve all the consumer protection standards, as well as to ensure the harmonisation of our country's legislation with that of the Community.

Furthermore, during the consumer legislation alignment process with that the acquis communautaire, a series of consumer policies were developed and implemented, placing health safety, product safety, consumer education, right to compensation, etc. The consumer protection policies that have been developed highlight consumer health related issues. Only a healthy consumer will be able to enjoy the rights granted to him/her by law. Except the Law on Consumer Protection, a series of other laws have been approved in the area of consumer protection, providing protection for the consumer in specific areas. (Ahmeti, 2006). The Law on Consumer Protection was designed by the lawmakers as a general framework of provisions in this area, defining the general rules for the consumer's protection. By adding up these specific laws to such a law, the Albanian lawmaker ensures a wider range of protection for the consumers (Ahmeti, 2006).

${ }^{1}$ The first law that was approved in our country is the Law no. 8192, dated 06/02/1997, for the protection of the consumer. Article 3 provides for the basic consumer rights which included the following: The protection of their health; The protection of their economic interests; The legal settlement of disputes; Setting up organisations and unions whose purpose is to protect the consumer's interests based on the legislation; The right to information 


\section{Methodology}

In this paper, I have chosen to review the positive steps made by our country towards protecting the consumer. The method that I have used in this paper is the qualitative one. The qualitative method is a mixture of the historical method with the explanatory one.

The historical method has been used in the first part of the paper, to demonstrate to us that consumer protection is new to our country considering that the term consumer did not exist in the previous legislation. The consumer law was approved for the first time after the political system changed. The consumer's legislation in our country has been changed in the course of the years. We can convincingly confirm today that the consumer law is the best one that has approved in this area.

The explanatory method is present in most of the paper. I have used this method to explain all the positive steps made by our country in undertaking the necessary measure to enable the Albanian consumer to enjoy the same protection that consumers of other countries enjoy.

The purpose of this paper is to indicate how the consumer protection level in our country has increased and the state mechanisms have impacted consumer protection.

\section{Measures Implemented for the Consumer's Health Protection}

Measures that aim to protect the consumer's health have continuously been approved and implemented. These measures must not aim to protect the consumer in general, instead they should also involve the protection of specific groups of consumers. One of the novelties introduced by the 2008 law is the introduction of Albanian labels on the products. The information provided in the labels must be accurate (Halilaj, 2015). In the case of "Tepelena Water", the information that was provided was false, representing a clear abuse of the competencies of the competent body that had certified the quality of this water (the Consumer Protection Committee, 2010). Everyone expects to have detailed information on the ingredients of the products we buy. Therefore, every nutritional product intended for consumption by human being, must bear information in Albanian in the label of the product (Law no 9902,"On the Protection of the Consumer", Article 8). It is only by reading the available information in Albanian that the consumer will be able to make the right choice for himself. By making a good choice, based on the information provided in Albanian on each and every product that the consumer has access to in the market, he will be able to make the right choice for himself and the others around him. Even though the use of Albanian in the labels emerged as a necessity, this element was still not enough to protect the consumer's health. This assurance element is an constant fight with the hygienic conditions in which the products are traded. The provision of adequate trading conditions for the nutritional products still represents a problem. One of the main objectives in 2015, for a healthier consumer, was the undertaking of measures and the assurance of adequate hygienic-sanitary conditions for the products being traded in the markets of our country. The conditions in which livestock were being slaughtered and traded represented a problem for our country. Following the measures undertaken by the National Food Authority, there is now more assurance for the consumer's health. The greatest issues identified by the NFA were located in the district of Tirana (The Telegraf, December 2015). The lack of appropriate conditions for the traded products increases the risks and chances of every consumer to face harmful consequences for the health as well as different diseases. The measures undertaken by the NFA today, in the markets where meat is being traded, have improved the hygienic-sanitary conditions and the consumer now feels more safe.

However, except having the right to safe products, consumers also have the right to demand for non-nutritional products available in the market to be safe for their health. This obligation lies with the traders which have to offer safe non-nutritional products in the market (Law no 9902,"On the protection of the consumer", Article 5). Each and every consumer, regardless of age, is threatened by products that are harmful to their health. It is in the children's nature to play more with toys. The toys of the company "MATEL" were removed by the Albanian market because they contained lead, which is harmful for children's health (Zajmi, 2010).

In 2016, the National Food Authority undertook all the necessary measures to prevent the trading of Snickers chocolates in the domestic market considering that it represented a threat for the consumer's health. The case of Snickers chocolate, which contained plastic matter harmful to the consumer's health (The Guardian, February 2016), represented a direct risk to the latter, therefore the NFA banned the product and ordered the withdrawal of this chocolate from the market.

\section{How Safe are we when it Comes to Consuming Genetically Modified Products?}

There is a great variety of nutritional products in the market. These nutritional products are divided into biological 
products (bio) ${ }^{2}$ and into modified ones. The consumer is quite often attracted by the external appearance of the product and neglects aspects such as actual quality and nutritional values. Allowing yourself to be seduced by the "beauty" of the product, while neglecting its quality, means self-inflicting damages to your health and to that of the other consumers. Bio and genetically modified products circulate in the market. All the products that contain hormones trigger panic among the Albanian consumers. At the moment, consumers aim at buying bio products by leaving the modified ones in the "shade" (USAID, 2013-2014). The consumer has little faith on its health safety if he/she consumes modified products. The tolerance towards these products is low. This is indicated by the panic that the circulation of tomatoes in the market triggered, once they were suspected of containing hormones. Following the NFA tests, it was concluded that there were no elements which would classify those tomatoes as genetically modified nutritional product (NFA, 2015).

The producer bears the responsibility of indicating genetically modified products by placing the respective indicative sign on the product. The purpose of this action is to inform the consumer in advance so that he/she can then make a free choice on whether he/she wants to consume these products or not. The non-implementation of this obligation does not avert the producer from having defrauded the consumer. The consumers' trust towards the modified products has dropped considering that they fear that the level of hormones might be too high. The excess by the producer of the level of hormones used on products such as: tomatoes, cucumbers, melons, to make them quickly marketable, is harmful to the consumer's health. These nutritional products are regarded as harmful to the human being's health because they contain high levels of acidity, which is not easily absorbed by the human organism. For these reasons, it becomes a triggering factor that harms health and that causes different diseases in the organism. What we notice is that the level of trust on modified products is very low. In all the cases when these products are allowed to be traded in the "wholesale and retail markets" 3 they must be equipped with an etiquette that clearly indicates that the product in question has been modified. Every consumer has the right to be informed on these products and this right cannot be negated to him/her for any reason.

\section{The Role of the National Food Authority in Protecting the Consumer's Health}

The National Food Authority is the competent body that undertakes inspections on the quality and safety of the food products traded in the market, also through the directorates that it has in different districts of the country (Halilaj, 2015). The objective of this body is not limited only to food quality and safety inspections, but it also extends to undertaking measures necessary to protect the consumer's health (Halilaj, 2015). If the nutritional products meet the required production and trading standards, we might say that the consumer's health has been protected. The NFA has undertaken periodic inspections in the markets, inspections that have primarily focused on the following:

1- the hygienic-sanitary conditions of the premises of operators that produce, assemble, store and trade nutritional products.

2- the hygienic-sanitary conditions of the employed personnel during the technological production, warehousing and trading processes.

3- the hygiene of the equipment and of the technological lines during the production, packing, transporting and trading processes of nutritional products.

4- the hygienic-sanitary conditions for the preservation and processing of the raw material used to produce nutritional products

5- hygienic-sanitary conditions of the imported products.

6- the hygienic-sanitary conditions of the economic operators that trade nutritional products in the wholesale markets.

7- the technological conditions required for the marketability of a product (packing, labelling).

8- inspecting and detecting the structure and location of businesses operating in the area of nutritional products production.

The inspections carried out by the NFA indicated that the following nutritional products have to undergo laboratory tests: eggs, byproducts, fish, dough products, oil, as follows: (NFA, 2015)

\footnotetext{
${ }^{2}$ By bio products we refer to all those products that are produced in an original way from soil, without the intervention of production modifying elements.

${ }^{3}$ From 2012 to 2015, the following product inspection have been undertaken in the market: Mandarins (Citrus Nobilis); Apples (MalusDomestica); Pears (PyrusComunis); Oranges (Citrus Sinensis); Kiwi (ActinidiaChinensis); Tomatoes (L.Licopersicum); Lemons (Citrus Limon); Watermelons (CiprillusAedulis); Peaches (Persica Vulgaris); Pineapples (A.Sativa); Salad rocket; Melons (CucumisMelo) Grapes (VitisVinifera); Peppers (Capsicum Annum); Aubergines (SolanumMelongena)
} 
1. Microbiological analysis;

2. Physical analysis;

3. Chemical analysis.

The nutritional products that are not accompanied by the respective labels are banned from being traded in the market. The measures that have been undertaken emerged as necessary because the consumer's health is at any moment endangered by the consumption of these products. The inspections that have been carried out have identified abuses with the trading of olive oil and honey. After the inspections, these nutritional products were banned from being traded in the market under the same conditions. The products to which the consumer has access to in the market, must bear a label which provides accurate and detailed information on the ingredients. Is it necessary to apply labels on nutritional products that do not expire, such as honey? Every nutritional product has to be accompanied by an etiquette. The labelling of the products is a legal obligation. A products does not undergo any classification on the basis of the expiry date, to get labelled. The labelling of honey is obligatory because the label has to provide the honey's origin, e.g. whether it is basswood honey, chestnut honey, mountain honey, flower honey, etc...

Providing the origin of the honey in the labels informs the consumer on the honey that he/she is going to use and protects his/her health directly because specific consumer groups may not be willing to us a specific type of honey considering that it might be hurtful to their health because of any health problem that they might have. As a conclusion, we mights say that labelling is not related solely to the product's expiry date, but also to the consumer's right to get information on the product and its ingredients.

However, the NFA has undertaken inspections also on trading units that produce and pack potable water. Four potable water production and packing lines carry out their activity in the district of Vlora. These operators have been inspected during the summer period and they have undergone laboratory analysis which proved that they meet the required standards necessary for a product to be considered as safe (NFA, 2015).

\section{Conclusions}

In the last couple of years we notice that several laws and a series of measures have been enforced with the purpose of protecting the consumer. Today, the consumer enjoys the protection of his/her health and the information he receives is considerable.

Through product labelling, consumers are informed on the product's ingredients and on the quality of the product, as well as the consequences that is may directly have on its health. What we notice is the presence of modified products in the wholesale and retail sales markets. Not every consumer is willing to consume such products. The consumer makes a selection of the nutritional products he/she is willing to buy hence the producer has the obligation to put the modification mark on the products' labels in order to inform and protect the consumer.

The institutions responsible for defending the consumer in our country appear to be more empowered. What is noticeable, is that the NFA has provided and continues to provide an important contribution through the inspections that it carries out in the markets, on trade units, leading them towards compliance with the legal provisions. Non-compliance with the conditions required for trading a product, turns them into harmful sources for the health of each and every consumer.

\section{References}

Ahmeti, A. (2006). The right of the consumer and the approximation of legislation with Community law. The School of Magistrates. Anastasi, A., Bozo, A., Mandr, A., \& Shkurti, E. (2014). Barazia gjinore dhe mosdiskriminimi. Tirane: Pegi.

Annual analysis of NFA.( 2015). 1, 10-13.

Case No.4 of Consumer Protection Committee, dated 30.07.2010

Halilaj, B. (2015). Consumer Food Safety in Albania, 5th International Conference on Humanities and Social Sciences, Rome-Italy. 1, 218.

Halilaj, B. (2015). Consumer Food Safety in Albania. Academic Journal of Interdisciplinary Studies. 4, 171.

Law No. 8192 dated 06.02.1997 " On consumer protection ".

Law No. 9135 dated 11.09.2003 " On consumer protection ".

Law No. 9902 dated 17.04.2008 "On protection of consumers".

Law Nr. 9199, dated 26/02/2004 "On the production, processing, certification and marketing of products" Bio "

Malltezi A.(2001). E drejta shqiptare e shoqerive tregtare, Tirane: mediaprint.

Omari, L. (2004). Shteti i se drejtes, Tirane: Elena Gjika.

Stabilization and Association Agreement. (2009). 
Teliti, E. (2013). Kontratat konsumatore:Kredia konsumatore, 2013, Doctoral thesis, [Online] Available: http://www.doktoratura.unitir. edu.al/wp-content/uploads/2013/08/Doktoratura-Ersida-Teliti-Fakulteti-i-Drejtesise-Departamenti-i-se-Drejtes-Civile.pdf (June 12, 2012)

The Annual analysis DRAKU-Vlora. (2015). 1, 11-18.

The Constitution of the Republic of Albania. (1998).

The Guardian. [Online] Available: http://www.theguardian.com/lifeandstyle/2016/feb/23/mars-chocolate-product-recalls-snickers-milkyway-celebrations-germany-netherlands ( February 23, 2016)

The Telegraf. [Online] Available: http://telegraf.al//aktualitet/taulant-kalo-aku-e-tiranes-ka-nen-kontroll-te-plote-higjienen-origjinensigurine-ne-prodhimin-dhe-tregjet-ushqimore (December 17, 2015)

USAID. (2013). Manual trajnimi: Pergjegjesia parakontraktuse, formimi dhe interpretimi i kontratave.

USAID. (2014), Hyrje ne kursin per mbrojjen dhe zbatimin e markave tregtare.

Zajmi, I. (2010). The European Common Market. Tirana:Ombra OVG. 
ISSN 2039-2117 (online)

ISSN 2039-9340 (print)
Mediterranean Journal of Social Sciences MCSER Publishing, Rome-Italy
Vol 7 No 6 November 2016 